\title{
24. CRETACEOUS-TERTIARY INVERTEBRATE MACROFAUNAS, LEG 120, SOUTHERN KERGUELEN PLATEAU, INDIAN OCEAN ${ }^{1}$
}

\author{
Patrick G. Quilty²
}

\begin{abstract}
Bivalves, calcareous worm tubes, and an irregular echinoid are described and illustrated from Cenomanian/ Turonian, upper Campanian, and middle to upper Eocene sediments recovered from several holes penetrated by Ocean Drilling Program Leg 120 drilling. Environments represented include deep-sea oozes and inner-continental shelf depths. All fossils are identified to genus but are left in open nomenclature at the specific level. The occurrence of Pycnodonte (Crenostrea) sp., an oyster, in deep-sea sediments seems unusual.
\end{abstract}

\section{INTRODUCTION}

This paper documents the few macrofossils recovered from Sites 747 to 751 drilled during Ocean Drilling Program (ODP) Leg 120. Macrofossils are rare in samples from the Leg 120 program, but they are important scientifically because of their isolation from surrounding land masses; because of the lack of macrofossil data in the large area of the Indian Ocean; and because of the unusual setting of the Kerguelen Plateau tectonically, historically, and geologically.

The few macrofossils recovered represent a diverse group of organisms, and no specialist can be expected to be an expert in all of them. The faunas include bivalves, calcareous worm tubes, and an echinoid. The coeval equivalents from the nearby continents have not been studied in detail, and thus the results of this study stand in geographic isolation. It will be a long time before they can be integrated into general Indian Ocean syntheses for the particular taxonomic groups. In addition to the whole-body fossils documented here, macrofossils have been important contributors to the sediments cored during Leg 120. In particular, the bivalve Inoceramus is an important contributor in all Cretaceous sections and unidentified echinoderms are common elsewhere.

The following identifications and comments on significance must be seen as tentative and subject to major revision in the light of subsequent circum-Indian Ocean studies, partly catalyzed by these records. The paleoenvironmental interpretations of the individual records are based on the study of the accompanying foraminifer (Quilty, this volume) and calcareous nannoplankton (Watkins, this volume) biota, and the taxonomic studies should be read in that context.

\section{SYSTEMATIC PALEONTOLOGY}

Specimens recorded are cataloged in two collections. A "wholeround" specimen (Sample 120-748C-73R-6, 128-130 cm) contains Camptonectes sp., Panopea sp., and Spirorbula sp. It is housed at the ODP collection in the routine core repository. Other material from oozes and indurated samples is contained in the Commonwealth Palaeontological Collection (CPC) held by the Bureau of Mineral Resources, Geology and Geophysics, Canberra, A.C.T., Australia. Catalog numbers are shown on the plate explanations.

\footnotetext{
${ }^{1}$ Wise, S. W., Jr., Schlich, R., et al., 1992. Proc. ODP, Sci. Results, 120: College Station, TX (Ocean Drilling Program).

2 Australian Antarctic Division, Channel Highway, Kingston, Tasmania, Australia, 7050.
}

\author{
Phylum MOLLUSCA \\ Class BIVALVIA Linné, 1758 \\ Subclass PTERIOMORPHIA Beurlen, 1944 \\ Order PTERIOIDA Newell, 1965 \\ Family PECTINIDAE Rafinesque, 1813 \\ Genus CAMPTONECTES Agassiz, 1864 \\ Subgenus CAMPTONECTES Agassiz, 1864 \\ Camptonectes (Camptonectes) sp. \\ (Plate 1, Figs. 1-3)
}

Material. Several specimens occur in glauconitic siltstone from Sample $120-748 \mathrm{C}-73 \mathrm{R}-6,128-130 \mathrm{~cm}$. Most specimens are fragmentary, and only three are of real value as they give information on external details and dentition of both valves. Other fragments show that the external sculpture is not carried through the valves to the interior.

Description. The species is small, robust, and fairly thick shelled for species of this genus. It is usually $10 \mathrm{~mm}$ in its dorsoventral dimension and 8-9 $\mathrm{mm}$ long. All fragments seen are consistent with this being the normal size for the species. The midline is approximately perpendicular to the hinge line and the specimens are approximately equivalve. The exterior of valves has many radial ribs about a marked divergence at the midline. The ribs are stronger and slightly more numerous near the margin, and arise by intercalation. Bifurcation was not observed.

Concentric sculpture consists of growth lines and irregular crenulations caused by variation in growth parameters. Sculpture does not penetrate to the interior of the shell except for the radial ribs near the margin and the irregular crenulations throughout. Interior surfaces are otherwise smooth. Musculature was not seen. Auricles are thick and robust, the anterior one the larger. External sculpture of auricles was not seen. The hinge line is $6 \mathrm{~mm}$ long with a resilifer $2 \mathrm{~mm}$ from the posterior end.

Remarks. This small species seems to have been quite abundant where it occurs in shallow-water sediments in association with the worm tube Spirorbula sp. and other unidentified small shells. All are robust and consistent with being from an environment of energy high enough to disarticulate the specimens but not turbulent enough to cause abrasion of the specimens.

Age. Cenomanian/Turonian.

$$
\begin{gathered}
\text { Family ENTOLIIDAE Korobkov, } 1960 \\
\text { Genus ENTOLIUM Meek, } 1865 \\
\text { Entolium sp. } \\
\text { (Plate 1, Figs. } 4 \text { and 5) }
\end{gathered}
$$

Material and remarks. A single crushed and flattened specimen was recovered from the glauconitic siltstone of Sample 120-748C54R-CC. The specimen has an orbicular shell, $18 \mathrm{~mm}$ in its dorsoventral dimension and perhaps $15 \mathrm{~mm}$ long. The shell surface is smooth other than for very fine growth lines. Under magnification it is clear that there are also abundant, very fine radial lines. The valve is probably a left valve, with the anterior auricle only partly preserved. Here the fine radial sculpture dominates and the valve nearest the 
auricle has the best developed sculpture of all even though still subtle. Further information is unavailable.

Age. upper Campanian.

Family GRYPHAEIDAE Vyalov, 1936

Genus PYCNODONTE Fischer de Waldheim, 1835

Subgenus CRENOSTREA Marwick, 1931

Pycnodonte (Crenostrea) sp.

(Plate 1, Figs. 6-10)

Material. Several fragmentary specimens with well-preserved features occur in Sample 120-749B-3H-1, $112 \mathrm{~cm}$. The description below is based almost entirely on this material. Other specimens are from Sample 120-749B-6H-CC.

Description. The shell is small and subcircular to elongate in a dorsoventral direction; the maximum size (height $\times$ length) is $19 \times 14$ $\mathrm{mm}$, with normal length about $10 \mathrm{~mm}$. Valves are fragile, thin, brittle, and commonly broken. Lamellae are commonly separated by thin gaps. Sporadically, the shell is composed of vesicular calcite. The surface is marked only by concentric growth lines; otherwise, it is smooth. The surface is irregular but it lacks costae or rugae. The surface of commissure is plain, and the growth form is irregular.

Although attachment is assumed, neither a substrate nor a clear large attachment area are obvious, although some specimens have a small attachment area on the umbonal region. The hinge area is divided simply into anterior and posterior bourrelets by a simple resilifer. Muscle scars are not well marked but are approximately central. Chomata are sporadically well-developed but are restricted in distribution to a zone close to the hinge and only on one side of the valve. A proximal gill wheal is well preserved on some specimens.

Remarks. This species occurs in a thin horizon of middle to upper Eocene ooze in Cores 120-749B-3H to -6H (15.3-53.3 mbsf). The presence of oysters in deep-water sediment is anomalous. The environment seems to have been that of a normal open-ocean ooze. Modern oysters that are closely appressed develop irregular growth forms because they are affected during growth by being crowded.

The source of the material is unknown, but attachment to some unidentified substrate is indicated, although the small attachment areas give no clue to what the substrate may have been. Specimens are small, suggesting that they were floating juveniles in an epiplanktonic life mode. Perhaps the attachment was to wood or kelp or perhaps there was a nearby island to act as a source of floating substrates over a period of a few million years.

The subgeneric name is applied only tentatively because, although the diagnosis of Crenostrea encompasses the material recovered, there is a marked size difference between the species described by Marwick (1931) and the specimens seen here, suggesting a comparison between the adults of one population and the juveniles of another. Also, only three or four specimens form the basis of the discussion here.

Age. Middle to upper Eocene.

Environment of deposition. Carbonate ooze with no evidence of close land.

\section{Subclass HETERODONTA Neumayr, 1884 \\ Order MYOIDA Stoliczka, 1870 \\ Family HIATELLIDAE Gray, 1824 \\ Genus PANOPEA Menard, 1807 \\ ?Panopea sp.}

Material and remarks. One fragmentary specimen was recovered from the Cenomanian/Turonian glauconitic siltstone in Sample 120$748 \mathrm{C}-73 \mathrm{R}-6,128-130 \mathrm{~cm}$. The specimen is unidentifiable, but it is an elongate form sculptured only with growth lines. No further details are available.

$$
\begin{gathered}
\text { Phylum ANNELIDA Lamarck, } 1809 \\
\text { Class POLYCHAETIA Grube, } 1850 \\
\text { Order SEDENTARIDA Lamarck, } 1818 \\
\text { Family SERPULIDAE Burmeister, } 1837 \\
\text { Genus SPIRORBULA Nielsen, } 1931 \\
\text { Spirorbula } \text { sp. } \\
\text { (Plate 1, Figs. } 11 \text { and 12) }
\end{gathered}
$$

Material. There were several specimens (only two complete) in the glauconitic siltstone. The material was studied in its matrix and not separated from it. Many other specimens are buried in the rock, but they could only be extracted at the expense of specimens of other fossils. This was taken to be unwise.

Remarks. This form is common in Sample 120-748C-73R-6, 128 $131 \mathrm{~cm}$, where it is represented by roughly planispirally coiled, biumbilicate calcareous tubes, the total fossil up to approximately 7 $\mathrm{mm}$ in diameter. The tube expands regularly in diameter without constrictions. The maximum diameter of the tube is approximately 1.5 $\mathrm{mm}$.

The outer part of the tube is essentially smooth but with closely spaced fine growth lines. There are no ribs parallel or transverse to growth lines on the distal part of the coils. The outer whorl embraces the inner whorls to a very large degree, generating a deep umbilicus on both sides of the coil, which shows the growth of three or four whorls. There is no evidence in the umbilicus of ribs parallel to the coil. The tube is essentially circular in cross section, but it is truncated on the proximal side where it envelopes the previous whorl.

Age. Cenomanian/Turonian.

Environment of deposition. Inner continental shelf, fully marine.

Phylum ECHINODERMATA

Class ECHINOIDEA Leske, 1778

Order SPATANGOIDA Claus, 1876

Family TOXASTERIDAE Lambert, 1920

Genus HETERASTER d'Orbigny, 1853

Heteraster sp.

(Plate 1, Figs. 13-16)

Material. A single specimen occurs in Sample 120-748C-51R-1, 4-6 cm; it consists of an original test with a collapsed aboral surface. Lateral and oral aspects are well-preserved without apparent distortion. The aboral surface is difficult to interpret in part because of the absence of an apical system. The external mold is poorly preserved and covers only the oral surface, particularly the posterior. The sediment containing the fossil is a typical marl, but it is a little more indurated than that term usually suggests.

Description. The body of the test is $25 \mathrm{~mm}$ long and $26 \mathrm{~mm}$ wide with an estimated height of $14-15 \mathrm{~mm}$. The point of greatest width is $11 \mathrm{~mm}$ from the anterior end. The anterior end is approximately semicircular; the test then tapers gently to the blunt posterior end, which is $11-12 \mathrm{~mm}$ wide and vertical. The aboral surface was probably a low dome highest at its midpoint near the apical system, which maintained this height to the posterior margin. The surface sloped anteriorly from the high midpoint.

The anterior aboral-ambulacral area is depressed and nonpetaloid. The depressed areas continue over the front of the test, onto the oral surface, and eventually to the mouth. The anterolateral-ambulacral areas are petaloid and apparently depressed, but this may be a function of preservation; they extend from the apical system twothirds of the distance to the test margin. From here they extend as weak depressions over the margin and cease as a depression at the edge of the oral surface. The other ambulacral areas and apical system are not preserved. The apical system is approximately central and perhaps a little anterior of the center.

The oral surface is essentially flat with a small peristome, $2 \mathrm{~mm}$ wide, and well anterior, with a well-developed lip on the posterior portion. The posterior ambulacral areas diverge from the peristome at about $30^{\circ}$; they are flat, smooth, and very gently depressed, becoming less distinct posteriorly as well as covered with tubercles at the posterior end. The posterolateral part of the test shows signs of abrasion, on the tubercles and on the plates. The anterolateralambulacral areas on the oral surface are very weakly expressed. The periproct is high on the flat vertical posterior surface and is circular, $2 \mathrm{~mm}$ in diameter and $5 \mathrm{~mm}$ above the base of the posterior surface. No fascioles are obvious.

Remarks. The name Heteraster is applied a little tentatively because the important characteristics of the anterior ambulacrum on the aboral surface are not preserved. The specimen is very similar in form to Heteraster trigonalis Desor as figured by Durham et al. (1966).

Age. Upper Campanian.

Environment of deposition. Shallow, fully marine, probably inner continental shelf. Sediment input was a mixture of calcareous fine material and fine terrigenous sediment, now represented by glauconite. 


\section{ACKNOWLEDGMENTS}

I thank M. R. Banks, University of Tasmania, and J. Laurie, Bureau of Mineral Resources, Geology and Geophysics, for their assistance with the photography of this material.

\section{REFERENCES}

Durham, J. W., Caster, K. C., Exline, H., Fell, H. B., Fischer, A. G., Frizzell, D. L., Kesling, R. V., Kier, P. M., Melville, R. V., Moore, R. C., Pawson, D. L., Regnell, G., Spencer, W. K.,
Ubaghs, G., Wagner, C. D., and Wright, C. W., 1966. Part U, Echinodermata 3, Volume 2. In Moore, R. C. (Ed.), Treatise on Invertebrate Paleontology: Lawrence, KS (Geol. Soc. Am. and Univ. Kansas Press), U367-U695.

Marwick, J., 1931. The Tertiary Mollusca of the Gisborne district. Paleontol. Bull. N. Z. Geol. Surv., 13:1-177.

Date of initial receipt: 30 April 1990

Date of acceptance: 1 October 1990

Ms 120B-176 


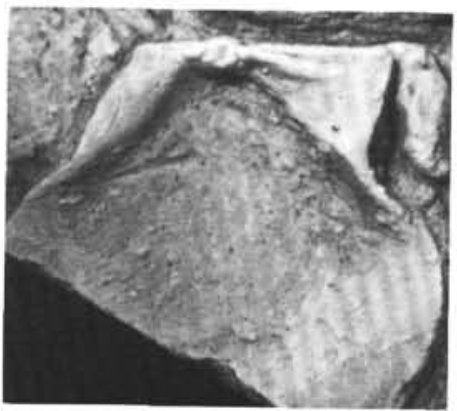

1

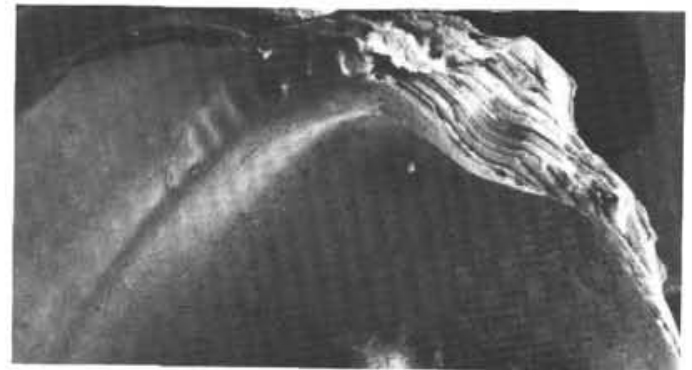

6

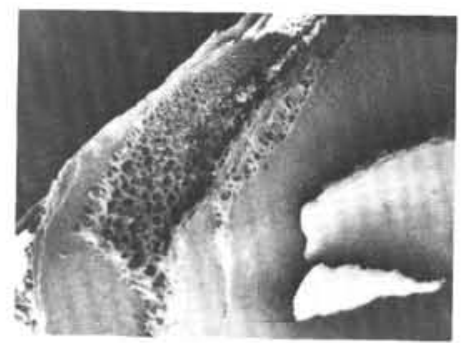

8

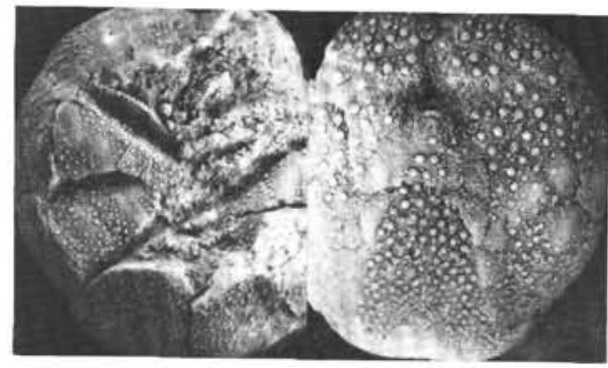

13

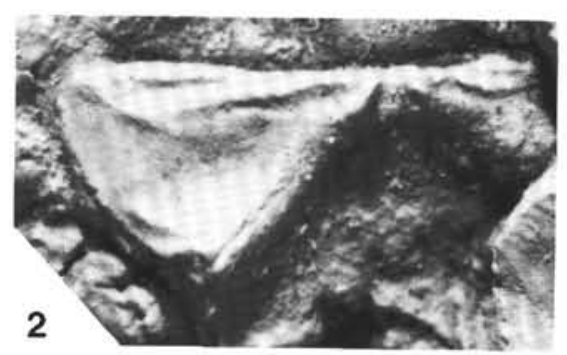

3
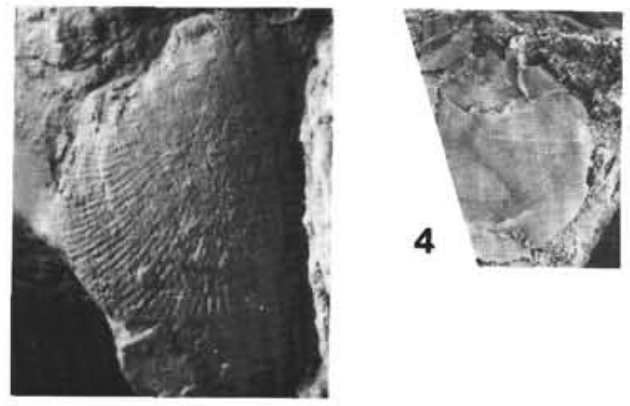

5

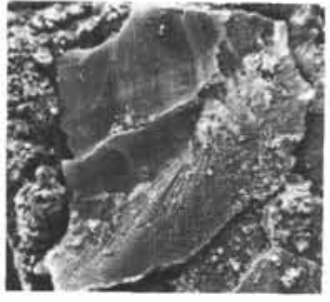

7
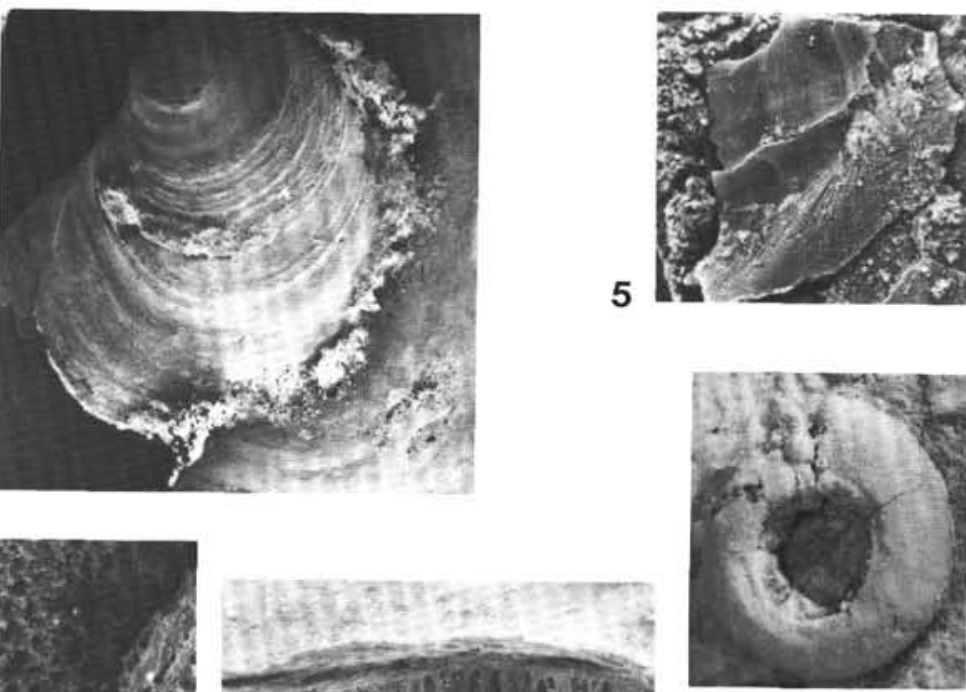

11

10

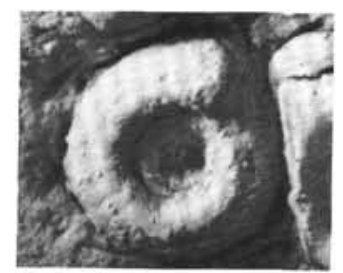

12

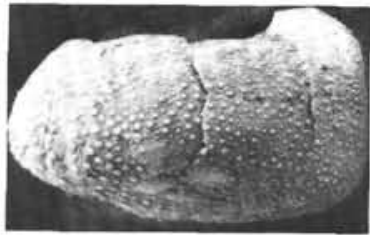

14

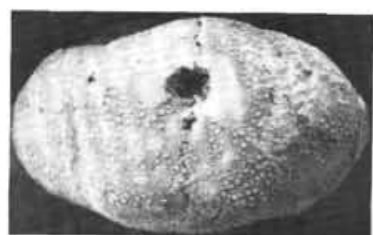

15

Plate 1. 1-3. Camptonectes (Camptonectes) sp., Sample 120-748C-73R-6, 128-130 cm, ODP collection. 1. Hinge area, left valve, $\times 4.5 .2$. hinge area, right valve, $\times 8$. 3. exterior right valve, $\times 3.3 .4$, 5. Entolium sp., Sample 120-748C-54R-CC, Commonwealth Palaeontological Collection (CPC) 28973. 4. Exterior left valve, $\times 1.4 ; 5$. enlargement of auricle of Figure 4, $\times 8$. 6-10. Pycnodonte (Crenostrea) sp., Sample 120-749B-6H-CC. CPC 28974. 6. Interior right valve showing chomata developed on one side of hinge, $\times 9$; 7. exterior left valve showing small attachment area, $\times 14 ; 8,9$. shell margin showing lamellar and vesicular structure. $8, \times 10 ; 9, \times 25.10$. side view of shell structure near shell margin with lamellar and prismatic vesicular ayers, $\times 60$. 11, 12. Spirorbula sp., Sample 120-748C-73R-6, 128-130 cm, ODP collection, opposite views of planispirally coiled, biumbilicate speciens. 11. $\times 4.8$. 12. $\times 3.4$. 13-15. Heteraster sp., Sample $120-748 \mathrm{C}-51 \mathrm{R}-1,4-6 \mathrm{~cm}$, CPC 28975. 13. Aboral and oral views, $\times 1.8 ; 14$. lateral aspect, anterior to left, aboral surface to top, $\times 1.8 ; 15$. posterior view showing periproct high in posterior face, $\times 1.5$. 